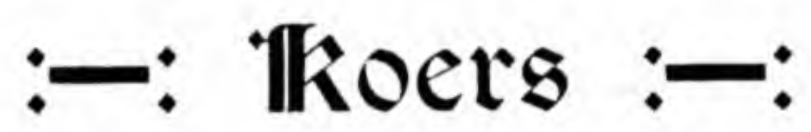

TWEEMAANDELIKSE TYDSKRIF

\begin{tabular}{lll}
\hline Jaargang XXIV & APRIL 1957 & No. 5 \\
\hline
\end{tabular}

\title{
Die Via Dolorosa
}

In die hartjie van Jerusalem, die heilige stad vir Jood, Mohammedaan en Christen staan daar 'n boog, die „Ecce Homoboog” genaamd, en ' $n$ klein endjie daarvandaan, die Heilige Grafkerk. Dit is die beginen eindpunt van die laaste lydensweg van onse Heiland. Dit dui die plek aan waar Pilatus sou gesê het, toe hy na Jesus gewys het: „Daar is die Mens" (Joh. 19:5). Hierdie pad, waarlangs Christus gegaan het vanaf sy verhoor en veroordeling, tot op Golgothashoogte, waar Hy gekruisig is, word genoem die Via Dolorosa, die Pad van Smarte. Dit is vandag ' $n$ bair smal straat. Hoe dit daar uitgesien het ten tye van Christus se laaste lydensgang weet ons nie, want Jerusalem is in die jaar 70 n.C. deur Titus totaal platgelê. Maar die puin van die geboue het die bodem bewaar en eeue later het die argeoloog L. H. Vincent inderdaad die Romeinse „Plaveisel” ontdek waarvan ons lees in Joh. 19: 13 , in Hebreeus „Gabbata” genoem. Jaarliks kom daar duisende pelgrims met Paasfees na hierdie gewyde oord, om in aanbidding die laaste lydensweg van Christus te betree. Of dit wel die juiste weg is, kan niemand vandag meer bewys nie, maar volgens oorlewering is dit tog dié weg-die via Dolorosa-en daarmee is die mense tevrede.

Die pad waarlangs die Heiland gegaan het, was nie baie lank nie. Net vier strate lank-maar vermoeiend steil. 
Die beginpunt was by die Antonia-brug en dit eindig in die Golgotakapel van die Heilige Grafkerk.

Daar is geen aanduiding, voor eers in die 13 de eeu n.C., van hierdie Via Dolorosa nie. In 1294 het Ricoldus van Monte Groce 'n plan opgestel wat die roete vasgelê het wat Jesus sou gevolg het op sy laaste lydensweg, volgens sekere gegewens wat hy vind in die Evangelies en sommige ook legendaries. En as die tradisie waar is dat Christus by die Antonia-brug verhoor is, dan is dit ook die aanneembaarste roete wat gevolg sou word. Daar is ook nog 'n ander gedagte dat die Tuingraf, net buite die Damaskuspoort, die graf van Jesus was. Maar die getuienisse is nie oortuigend nie. Ons is egter meer geneë om die tradisionele aanwysing van die Grafkerk te a.anvaar as die plek wat die meeste ooreenstem met die Skrifgegewens. Ten tyde van die evangeliste het die woord „Praetorium" nie juis 'n spesifieke plek aangedui soos min of meer ons geregshowe nie, maar alleen die plek waar die prokurator sy tribuun opgestel het om hofsake te verhoor, sy „Bema”-'n verplaasbare platform waarop sy regterstoel opgestel is. Hierdie plek het ook dikwels gewissel, soms in dieselfde plek en in dieselfde jaar na gelang van omstandighede. M.a.w. as ons die plek moet bepaal van Pilatus se „Praetorium” ten tyde van Christus se verhoor moet ons nie soek na waar hy tuis was in Jerusalem nie, maar moet vasgestel word waar hy op daardie Vrydagmôre die Sanhedrin ontvang het om hulle saak teen Jesus te ondersoek.

Tot onlangs toe is daar drie plekke in Jerusalem angewys wat aanspraak gemaak het daarop dat Jesus daar verhoor is, nl. (i) in die Antonia, (ii) 'n oordekte suilegang of laan en (iii) die paleis van Herodes. Lg. kan egter maar buite rekening gelaat word as onwaarskynlik aangesien Pilatus en Herodes in vyandskap geleef het met mekaar en Pilatus dus nie in Herodes se paleis sou tuisgaan nie.

$\Rightarrow$ ii Maar verder ook onlangse argeologiese opgrawings het aan die lig gebring dat die Antonia-vesting ten noorde van die Tempel-terrein wel die plek is waar Pilatus Jesus verhoor het. Inderdaad is hier ook ' $n$ terrein blootgelê wat ooreenstem met die Skrifgegewens-'n plaveisel wat al die eeue bedek was onder die puin van Jerusalem sedert die jaar 70 n.C. ,En toe Pilatus hierdie woord hoor, het hy Jesus buitentoe gebring en gaan sit op die regterstoel in die plek wat Plaveisel genoem word, en in Hebreeus Gabbata" (Joh. 19: 13).

Alles in aanmerking geneem, is die Antonia-vesting met sy Lithos- 


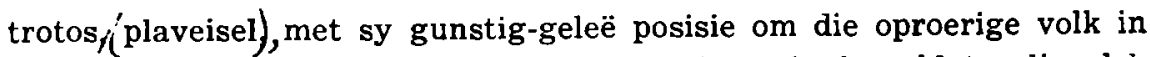
die oog te hou en te beteuel, met sy ingekwartierde soldate, die plek waar ons die praetorium van Pilatus vir ons moet voorstel. Dit is hiervandaan wat Sy kruisweg begin het.

In die jaar 70 n.C. het die Antonia-brug onder die swaar aanslae van Titus in puin gestort en so die lithostrotos of plaveisel toegedek. In die volgende eeu het Hadrianus op die puin van Jerusalem 'n Romeinse stad gebou met die naam Aelia Capitolina. Op die plek van die Antonia-vesting en lithostrotos het hy die Ooste-poort gebou. Hierdie poort was later bekend as die Boog van die Ecce Homo, en deur die eeue heen het dit die getuienis bewaar van die begin van Jesus se leaste lyde.

Jaarliks met paasfees word hierdie Via Dolorosa deur duisende pergrims besoek en betree om in 'n stemming van aanbidding hier te vertoef op die weg wat ons Heiland gegaan het. Nie net met paasfees

î nie; maar gedurig kom daar pelgrims van oor die hele wêreld van elke kerk en geloof, kerkleiers, studente en soldate, toeriste en boere, $j 3 /$ van elke nasie en ras en stand kom hulle saam op hierdie weg. Die Roomse en meer ander kerke kom elke Vrydag in heilige optog deur hierdie smal en skilderagtige straat en vertoef dan in devosie by die verskillende momente of stasies van die kruisweg/wat duidelik aangemerk is op die mure van die ou geboue tot by die Grafkerk.

Op Sy lydensweg is daar verskillende momente wat die Skrif vir ons spesifiek noem, en hiervan en van 'n paar ander, volgens oorlewering, het die Roomse kerk veertien stasies gemaak waar die pelgrims dan vertoef in aanbidding. Op hierdie weg is nl. 3, 4, 6, 7, en 9 volgens oorlewering, en die ander volgens Skrifgegewens vasgestel.

Eers in die 16de en 17de eeu het die gerk hierdie getal van veertien geyk deur die Congregatio Indulgentiarum, en 'n afbeelding van die stasies is in alle Roomse kerke te vinde.

Die begin is, soos reeds gesê, by die Ecce Homo-kapel, gebou aan die Boog bo-oor die straat met die anwysing „Ecce Homo-boogej) Hier is ' $n$ plaat aangebring met die woorde:

\author{
VIA DOLOROSA \\ AD ARCUM ECCE HOMO \\ UBI PONTIUS PILATUS \\ CHRISTUM \\ JUDAIS TRADIDIT UT CRUCIFIGERETUR.
}


„Via Dolorosa, na die Ecce Homo-boog, waar Pontius Pilatus Christus oorgelewer het aan die Jode om gekruisig te word."

Hier is die ,plaveisel", die Gabbata van Joh. 19, waar Christus veroordeel is. In die kerkie word besoekers allerlei aandenkings en relikwieë getoon wat in verband met Christus se lyde staan, soos bv. die kleed waarin Christus se liggaam toegedraai was in die graf, wat nou hier bewaar word!

Met steil kliptrappe klim jy op na die volgende stasie. „En Hy het Sy kruis gedra en uitgegaan na die sogenaamde Hoofskedelplek, in Hebreeus, Golgota," (Joh. 19: 17). Die Antonia-vesting was 'n vesting aan die buitenste ringmuur om Jerusalem. Ek sien die „uitgaan” van Jesus dus dat $\mathrm{Hy}$ onmiddellik uit die stadspoort uit is. Ons moet onthou dat daar in die loop van die eeue verskeie mure om Jerusalem gebou is: die eerste mur in die tyd van Dawid en Salomo in 1050 v.C., die tweede muur is deur Nehemia herbou in 446 v.C.jwat die stad na die Noordweste uitgebrei het, en die Antonia-vesting was op die Aoordehoek. Direk na Sy veroordeling is Hy dus uit die stad uit. Die muur is vandag nie meer dieselfde nie, want daar is nog ' $n$ derde en vierde muur in later jare gebou, wat die stad steeds groter laat uitbrei het, sodat ook Golgota tans binne die stadsmure lê.

Die derde en vierdile stilhouplek is volgens oorlewering waar Jesus onder Sy kruis geval het en waar Hy Maria ontmoet het en waar sy flou geword het.

By die 5de stasie sou die soldate Simon van Cirene, wat van die veld af gekom het (Luk. 23: 26), gedwing het om die kruis van Christus te dra.

Daar is allerlei anekdotes van wat alles op elkeen van hierdie staanplekke sou gebeur het. So is daar by hierdie plek 'n verweerde klip ingemessel met 'n donker afdruk van 'n mens se hand. Dit word beweer dat dit die afdruk is van Jesus se hand toe $\mathrm{Hy}$ teen die muur aangeleun het. Kommentaar is natuurlik oorbodig.

Die sesde stasie is by ' $n$ kapel, halfpad teen die heuwel op. Hieraan is die legende verbonde van 'n Romeinse vrou, Bernice, wat Jesus so jammer gekry het toe $\mathrm{Hy}$ by haar huis verby gegaan het, dat sy die sweet van Sy gesig met haar doek afgevee het, en toe later die afdruk van Sy aangesig daarop gevind het. Sy is tot ' $n$ heilige verklaar met die naam ,die heilige Veronica." 
By die sewende stasie is daar 'n groot onnette kapel in ' $n$ besige markstraat wat die plek aandui waar Christus vir die tweede keer geval het. 'n Klein endjie verder op die muur, rondom die grafkerk, is die agste stasie. waar Hy die vrouens van Jerusalem tereg/gewys het/ (Luk. 23: 28). Die negende stasie, waar $\mathrm{Hy}$ die derde keer geval het, is by die trappies wat oplei na die dak van die Grafkerk, waar omtrent 80 swart Abbisynse Christene in hutte woon bo-op die groot Grafkerk.

In die vierkant voor die Grafkerk binne-in die ringmuur is daar 'n lang klip rusbank waar talle pelgrims kan sit en rus en bepeins.

Eindelik is 'n mens dan op die laaste terrein-Golgota-waar die res van die stasies sommer by mekaar is. Dit word alles oordek deur 'n koepelkerk.

D)

As 'n mens die Grafkerk yir die eerste keer sien, is jy diep teleurgestel. Dit is 'n somber kerk, van buite met pale en stutte gesteun om te verhoed dat dit pie verder verval pie. Binne-in is dit skemerdonker en moet jy met lang, dun kersies jou weg vind. Jou voorgestelde beeld van 'n graf, uitgekap uit 'n rots, verdwyn by die aanskoue van die marmer-kapel onder in die ronde dak. Die groot kerkgebou is in die besit van verskeie groepe. Ses verskillende Christelike kerke besit hulle eie kapelle met hulle eie voorregte, binnel in hierdie koepelkerk.

Die ophoping van allerlei ornamente in die kapelle is afstootlik vir ans Protestantse gevoel. Die plek is vol opsigtelike en pronkerige lampe en kerse, en buite-om is goedkoop en duur behangsels. Dit was dwarsdeur die eeue hier glo maar so.

Net binnekant die groot swaar houtdeur, links, is 'n breë rusbank waar 'n Mohammedaanse deurwagter, as neutrale persoon, die rus en vrede bewaar. Die regering het al gepoog om hom uit te koop omdat sy teenwoordigheid nie juis langer nodig is nie.

Reg voor jou, as jy inkom, is daar die langwerpige salwingsklip waarop die liggaam van Christus, volgens oorlewering, neergelê is vir salwing. (Dit is die dertiende stasie). Bo-oor en rondom hang daar

i) lampe en enormegroot kerse, en hoog bo troon die kaal en ruwe klipf gewelf. Balke, kruis en dwars, gee 'n indruk van onvoltooidheid en

7) vervallendheid. Tog is daar 'n atmosfeer van piëteit wat jy aanvoel. Dit kan eintlik ook nie anders nie, want na hierdie heilige oord het wi-d)

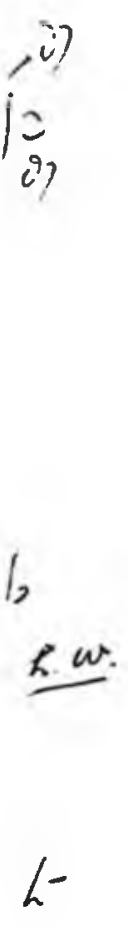


1600 jaar/al pelgrims van oor die hele wêreld gekom, elke uur en elke dag van dîe jaar.

Direk aan jou regterkant/as jy inkom, gaan jy met donker trappe op, 14 voet hoog na 'n platform op soliede rots, waarop die kruis $\hat{j}_{\text {kapel }}$ staan. Rondom die kapel is 'n onaansienlike kliptraliewerk met smal trappies weer aan die ander kant af.

Hier is dan die tiende stasie van die kruistog, waar die soldate Hom ontklee het en Sy klere verdeel het.

Reg voor jou is 'n Rooms-Katolieke altaar, hulle elfde stasie, met i) groot moderne mosaiek-ingelegde beelde om die vasspykering aan die kruis te vertoon. Dit is die Roomse gedeelte van die kruisplek, wat net met 'n paar pilare geskei is van die Griekse gedeelte. Onder die altaar moet jy inloer om die gat te sien waarin die kruis veronderstel was om ingeplant te wees. By die twaalfde stasie, 'n klein endjie na agter toe, is ook die ander twee gate, waar die moordenaars se kruise ingeplant sou wees. 'n Skeur in die rots, veroorsaak deur die aardbew fing met Christus se kruisiging, is regs sigbaar, waardeur Sy bloed sou gesypel het en toe dit die Skedel van Adam raak, hom weer laat herleef het!

Op hierdie verhoog is een altaar naas die ander om die gebeurtenisse op Golgota aan te dui. Bv. waar die vrouens gestaan en kyk het; waar Maria Magdalena die opgestane Heiland vir die tuinier aangesien het; waar Hy bespot is; waar die soldate die lot gewerp het oor Sy klere, en nog meer. Selfs ook 'n altaar vir die heilige Longinus, die Romeinse soldaat wat die swaard in Jesus se sy gesteek het. Hulle vertel dat hy blind was in sy een oog en dat die bloed en water uit Christus se sy, wat aan sy blinde oog gekom het, dit genees het en dat hy toe ook later bekeer is.

Met die trappies af, 45 treë vanaf die kruisplek, is diegraf van Jesus, die veertiende en laaste stasie van die Roomse Via Dolorosa. Die graf self is binne-in ' $n$ marmer kapel, wat in later jare daaroor gebou is. Om in die graf te kom moet jy laag buk, en dan is daar skaars plek vir 4 mense. Trosse lampe wat aan verskeie kerke behoort, h.?ng

in daar met weiniqg lig. Die mure is behang met verweerde materiaal, prente en behangsels van allerlei aard. En tog, al die behangsels en versierings ten spyt, oorweldig jou gevoel jou as jy ook op hierdie laaste eindpunt kom van die Via Dolorosa van onse Heiland.

Dit is tog interessant om die historiese verloop van die wel en wee van hier'lie heilige Grafkerk na te gaan. 
Die Grafkerk sluit in: die Kapel op Golgota; die salwingsklip; die kapel vaan die heilige graf; die Griekse katedraal; die kapel van die verskyning van Christus; die kapel van die ontdekking van die kruis, oorspronklik gebou deur Helena, die moeder van Konstantyn, in 336 n.C.

Dit is afgebreek deur die Perse in 614; weer opgebou deur Modestus in 616; herstel in 820 ; deur vuur beskadig in 936; afgebreek tot die grond toe in 969 deur Hakim die kranksinnige; herbou deur die Griekse keiser Michal IV in 1037.

In 1056 het die Kruisvaarders 'n Romaanse kerk gebou wat al die heilige plekke en kapelle ingesluit het. Dit is weer afgebrond deur die Tartare in 1244. Maar in 1310 het hier weeneens 'n mooi kerk verrys; uitgebreide herstelwerk is gedoen in 1400 en in 1717. In 1808 het byna die hele kerk afgebrand, per ongeluk? In 1810 het die Grieke en Armeniane groot fondse byeengebring vir die oprigting van die huidige gebou.

Hoe die Roomse beelde en tradisie jou ook al teenval,bly dit tog vir jou 'n groot ervaring om hier in die stad Jerusalem ook jou voete te sit op die weg wat Jesus gegaan het en in stille aanbidding te dink aan wat Hy gely het op sy Via Dolorosa vir Jerusalem en vir sy volk -en ook vir my.

\section{W. J. VAN DER MERWE.}

Vereeniging.

Om my geheue te verfris het ek ook gebruik gemaak van die volgende werke wat die moeite werd is om te lees vir elkeen wat iets meer wil weet van Palestina en van Jerusalem.

Werner Keller: Die Klippe het dit Uitgeroep.

H. V. Morton: In the Steps of the Master.

Pierre Loti: Jerusalem.

Leslie Farmer: We Saw the Holy City. 